\title{
Finding Your Voice in the Streets: Street Art and Epistemic Injustice
}

\author{
Sondra Bacharach*
}

\begin{abstract}
I argue that activists have co-opted street art as a tool for addressing epistemic injustices, injustices that result from negative identity prejudices that silence certain groups of people unfairly. To defend this claim, I explore the special nature of street art that makes it an especially appropriate tool for activists to enlist in the fight against epistemic injustices. From there, I will examine in detail two case studies which illustrate how street art is used to respond to and correct for these injustices: first, the street art series, "Stop Telling Women to Smile" by Tatyana Fazlalizadeh, and then Chris Metzger's Inside Out Project in Baltimore. Drawing on these examples, I highlight the features in virtue of which street art constitutes a particularly effective tool for correcting epistemic injustices.
\end{abstract}

\section{INTRODUCTION}

Street art has exploded—it pervades our back alleys, surrounds our bus-stops, covers up billboards, competes with advertising, and generally serves as wallpaper for most cities. We are used to visual noise surrounding us when we are out and about-a glut of graffiti, big advertisements, and local flyers envelop our entire visual field. We have learned to see through the eye pollution. But, recently, eye candy is slowly replacing the visual garbage: clever, witty, ironic, sarcastic, humorous, and interesting new art is popping up in unexpected nooks and crannies of cities all around the world. This new trend has more popularity and appeal with the ordinary public than most contemporary art.

More than just a pretty facelift for our streets, however, recent street art has been taking on an increasingly subversive, activist role, posing deliberate challenges to the status quo. Writing "Black lives matter" one thousand times on a wall publicly expresses a street artist's outrage over racism in the US; JR's Face to Face's oversized portraits of Israelis and Palestinians on the West Bank barrier normalizes interactions, thereby promoting tolerance; Marianne Jorgensen's 'yarn bombing' forcefully opposes the Danish involvement in the US-Iraq war with delicate pink knitting covering a military tank. Street art has suddenly been co-opted by activists of all stripes and for all causes. 
This paper explores how and in what ways activists have tapped into street art's activist potential as a tool for their social and political agendas. In particular, I argue that street art has been co-opted as a tool for addressing epistemic injustices, injustices that result from negative identity prejudices that silence certain groups of people unfairly. This requires exploring how street art's activism can be enlisted to fight epistemic injustice. To do so, first I will explore the special nature of street art's activism that makes it an especially useful tool for activists. Second, I'll provide an overview of the nature of epistemic injustice. This will provide the groundwork for an in-depth examination of two case studies where street art is used as a tool for responding to and correcting for epistemic injustice-hence street art's appeal as a tool for activists who seek to engage with and change the world. I conclude by highlighting the features in virtue of which street art constitutes a particularly effective tool for correcting epistemic injustices.

\section{STREET ART'S ACTIVISM}

Why this sudden shift in street art from mere aesthetic adornment to weaponry to fight for the cause of the month? Art has always been deeply socially and politically engaged-that is nothing new. Many art movements and theories have devoted themselves passionately to political and social causes in the past-think of Goya's Third of May 1808, Norman Rockwell's The Problem We All Live With, David's Death of Marat, Warhol's Big Electric Chair, or ancient Greek comedies. The connection between art and politics is long standing.

However, the way in which street art has become politicized is dramatically different from the way in which earlier art has been political (at least if one sets aside campaign and propaganda posters intended to elicit and direct action in favour of some policy or practice). Previous art movements used to be political in virtue of making a political statement in their art-they represented the situation in their artwork in a way that makes clear their political stance. Goya makes clear his own political views by portraying the innocent victim, helpless against the faceless executioners. Picasso's attitudes towards the atrocities of war are clear in Guernica's dismembered bodies, the distorted animals and horrific scenes of devastation and death. These artists express their opposition to a state of affairs in reality by representing their views about that situation in their art-for example, the painting invites a certain kind of response in the viewer (Third of May invites us to commemorate the Spanish resistance). In political art, art is a language through which to express oneself, a vehicle for expressing one's opposition or support for some cause or other, a medium in which to articulate a political world view. These works are political in the sense that they make a political statement; they communicate to the viewers a certain perspective on a situation or political view. But the ultimate goal of these paintings is to communicate their ideas and values to the world through their art, and if they're lucky, to persuade their viewers of the correctness of that representation.

But these works are not thereby activist in spirit-such works do not also set out to change the world with their art-making practices. But when artists choose to work in street art (as opposed to other art forms), they do so as an act of resistance. In this respect, street art is profoundly different from political art in its ultimate goal-it 
is not sufficient for street artists to simply convey a political view in their art. Instead, street artists make acts of resistance with their art. Street artists attempt, through their art, to do something about the world: they want to change the world with their artworks, literally!

This kind of activism is made possible because of street art's aconsensual methods of production-it is made on property whose owner has not provided consent. ${ }^{1}$ No matter what style, medium, or agenda, all street art is made without consent of the property owner. This aconsensuality in the public arena transforms the art-making process into an act of political and social protest. Aconsensuality is the umbrella concept under which the diverse facets of street art come together into a single, unified group that does justice to the social, political, environmental, and legal aspects of street art.

Activism itself can be realised or carried out in many different ways-by protest, by engaging in short-term actions designed to change a certain environment, or dedicating oneself to strategies that create alternative avenues of engaging with society to challenge the dominant methods. Recently, street art has become a preferred method for engaging in activism. This is a particularly effective strategy for effecting change in one's local environment. For example, one might ring one's local representative to complain about the potholes, or sign a petition. But an even more immediate and effective solution is to fill in the holes with yarn bombs comprised of colourful knitting or crochet, as a bright and temporary stop gap —it also sends an immediate message to every passerby that the local government is failing in its job and, by providing a (lively and fun) solution, enacts some public shaming of the governmental bodies by highlighting what a simple job such repairs are. ${ }^{2}$

Street art is also a very special and unique form of activism: by moving their art out of the museum and into ordinary life, street artists do not merely comment about the state of the world; they intervene and change our world with their works. Inserting art directly into the real world (instead of into the artworld) allows street artists to actively construct a different world to inhabit. Street art crosses the boundary between art and an actual act of protest. ${ }^{3}$

\section{EPISTEMIC INJUSTICE: AN OVERVIEW}

To defend the view that street art is a useful corrective for epistemic injustices, we need to begin by understanding what epistemic injustice is, how it arises, and what would be involved in correcting it. ${ }^{4}$ This is the task of this first section.

Some groups experience negative prejudices against members of the group in virtue of their identity. These prejudices are epistemically harmful in at least three ways: (1) they prevent speakers who experience the negative identity prejudice from being heard; (2) they deny access to knowledge to those who cannot hear the prejudiced groups; and (3) they impoverish the total knowledge base of the epistemic community. ${ }^{5}$ These harms themselves are epistemic in nature, because the prejudices reduce knowledge production, transmission, and retention. But the cause of these epistemic harms is social and political: negative identity prejudices operate within the social and political domain of every day life. Epistemic injustices of this kind 
highlight the degree to which negative epistemic consequences result from the problematic social and political structures and attitudes infiltrating our ordinary lives. ${ }^{6}$

Epistemic injustices arise when individuals are harmed in their capacity as a knower, and this in turn can occur in two ways-testimonial and hermeneutic. In the case of testimonial injustices, prejudices prevent the hearer from assigning the amount of credibility to the speaker that $\mathrm{s} /$ he is due. ${ }^{7}$ The hearer's negative identity prejudice causes the hearer to assign such a low credibility level to the speaker that the utterance fails to qualify as an assertion with truth content sufficient to count as a belief:

operation of identity power in epistemic contexts means that some social groups will find that their experiences are systematically neglected, ignored, or distorted by social discourses that they have little power to influence or change. ${ }^{8}$

The hearer's negative identity prejudice literally prevents him from hearing the speaker's words as an utterance worthy of belief. The speaker is thereby silenced and the testimony discounted.

Consider an example. A white police officer in the U.S. has a negative identity prejudice against blacks; as a result of the white police officer's negative identity prejudice, the police officer assigns a low credibility to the black person's utterance when a black person offers an utterance as testimony to the white police officer. The police officer assigns so little credibility to the black person's utterance that the officer cannot take his utterance as worthy of being believed; the black person's testimony is not heard. ${ }^{9}$

Negative identity prejudices like the police officer's prevent the oppressed groups' knowledge and experience from being heard by others; their voice is never heard, and so never gains any traction for change or recognition or acknowledgement by the social world at large. They are politically and socially ineffective as a result of never being heard or recognized.

In addition to testimonial injustices, an agent can also be harmed by hermeneutic injustices: "hermeneutical injustice occurs ... when a gap in collective interpretive resources puts someone at an unfair disadvantage when it comes to making sense of their social experiences ...."10 When a group lacks the conceptual resources to make sense of their experiences, then that group cannot express or articulate those experiences to others. As a result, that group's experiences are not validated as legitimate. This means those experiences are categorized as personal issues, rather than experiences that apply to a group that require attention or that deserve a response.

Consider Fricker's example of sexual harassment. Imagine that a woman lives in a time during which society lacks the conceptual resources to describe sexual harassment-a time when sexual harassment exists, but there is no concept that describes this behaviour. Without realizing that this experience of sexual harassment is a general phenomenon, the woman who experiences sexual harassment will assume it is a personal attack on her, rather than an instance of sexual harassment. She will not know that she can call out such behaviour as disrespectful to women; she will not be 
able to articulate her experiences to people either within her group (to other women) in any productive manner (it will remain described as a personal experience, rather than as a general behaviour that requires a group response). Her injustices remain unarticulated because the concepts or words that capture the inequities of the situation are missing-either from the group who experiences them (and so cannot express the harms that result) or from the social imagination at large (and so lacks the resources to process or understand what is being expressed).

Injustices, epistemic or otherwise, have been highlighted in the news all around the world, from the Black Lives Matter Movement in the U.S., to the European refugee crisis. But little attention has been directed at how to correct these injustices. That should come as no surprise-they seem quite daunting, because the root cause of these injustices runs both wide (social and political structures at issue pervade the very fabric of our everyday lives) and deep (the social and political structures at issue are ingrained in the structural institutions of our everyday lives).

Epistemic justice, testimonial or hermeneutic, would involve correcting for these negative identity prejudices, enabling the marginalized voices to speak and for their voice to be acknowledged and heard. Philosophers have offered up some solutions, e.g., foster epistemic virtues, encourage virtuous dispositions, but their practical application remains a bit vague. ${ }^{11}$

The challenge of course lies in the fact that most people harbouring negative identity prejudices either deny that they have them or refuse to accept that their prejudice has any real impact on their behaviour. The implementation of such philosophical fixes is not obvious at a practical level. How do we get recalcitrant hearers to replace their vicious lens of negative identity prejudices with more virtuous ways of hearing other people's viewpoints? How does one foster virtuous dispositions or hopeful trust to an entire community of prejudiced people-people who typically are sufficiently blinded by their prejudices that they will deny the very existence of an alternative reality? The challenges for correcting epistemic injustice stem in part because the negative identity prejudices do not just taint any one aspect of knowledge-the negative identity prejudices distort every single process of knowledge creation and transmission.

\section{STREET ART AS CORRECTIVE TO EPISTEMIC INJUSTICE}

One unexpected solution to this epistemic problem comes from art. In this section, I suggest that street art constitutes one simple, practical solution to addressing epistemic injustices: street art is a particularly powerful tool to help correct epistemic injustices because art provides conceptual resources that the public might otherwise lack, and because it offers an opportunity to give voice to people who otherwise lack a voice. Street art can be used as a tool to help provide a voice to those who have been silenced, which in turn means it can be used in certain cases to address testimonial injustices. When street art expresses and articulates the voice of those who have been silenced, it also thereby provides a voice for the marginalized. This helps to correct for epistemic testimonial injustices. Moreover, since street art is also visual (rather than linguistic), it can provide conceptual resources to articulate experiences, ideas, and values, even when the social imagination is missing the requisite conceptual or 
linguistic tools. So, street art can also be used to correct for hermeneutic injustices, by providing opportunities to visually articulate, express, and communicate ideas for which the social imagination lacks words.

\section{Case 1: Fazlalizadeh's "Stop Telling Women to Smile"}

Street art offers one possible solution to correcting for both testimonial and hermeneutic injustices resulting from negative identity prejudices. Consider testimonial injustices first, for example, when a woman experiences silencing as a result of being cat-called. This form of gender-based harassment encompasses many forms of silencing-but at least one result of cat-calling is that the woman is silenced. When a woman is cat-called, the perpetrator objectifies the woman in a way that prevents her from responding verbally, primarily because the woman, thus objectified, is denied her status as a rational human being who might be entitled to respond.

The cat-calling has effectively silenced the woman, thereby preventing her from being treated as a giver of knowledge. To appreciate this, think of what is objectionable about cat-calling. It is the way that cat-calling objectifies and silences. Being treated as a mere object means you are treated as something that will not respond or react to the cat-call. The woman experiences a testimonial injustice (among many different injustices) because as soon as she is objectified, she is denied the opportunity to speak up for herself and respond to the attack. ${ }^{12}$ Of course, the woman could theoretically respond. But, in most cases, a response would be stupid, risky, and possibly life-threatening. So, the injustice here seems to be an injustice of silencing, in which case the injustice originates in the silencing aspect, rather than the objectification aspect of the cat-call.

Correcting for the epistemic injustice incurred by a cat-call would minimally require giving the woman an opportunity to speak up or respond to the attack. Of course, simply responding directly to the attacker is dangerous, so this option is possible, but not practically viable. Street art affords a way of responding to one's attacker without the corresponding retaliatory risks.

Tatyana Fazlalizadeh has created a series of street artworks called "Stop Telling Women to Smile." ${ }^{13}$ The series consists of portraits of women who have been harassed in the streets; she interviews women who have experienced street harassment in the form of cat-calling - when it occurred, where, and the conditions under which it occurred. She then draws the woman's portrait, and invites the woman to respond to the harassment-which appears in a quote below her portrait. These images are affixed with wheat paste to the walls in the streets at the site of the injustice. In these cases, Fazlalizadeh's street artworks constitute a response to the testimonial injustice that silences the women: these works provide an opportunity for the women who were silenced by the harassment to regain their voice.

One might worry that these women have not had their injustice corrected, because the cat-callers themselves may never see the pictures and their responses. That is, one might think that an appropriate correction would involve not only giving women the opportunity to respond (as Fazlalizadeh does) but also to direct their response to the silencer, to the person with the negative identity prejudice. 
This additional requirement- to respond directly to the perpetrator of the injustice-places too stringent a requirement on epistemic justice. Notice these women regain their voice the minute their responses to the cat-callers are placed at the site of the attack-even if their attackers themselves never hear their voice. Fazlalizadeh's street art is a visual reminder that the person is a person, a person who has a voice. By placing the victim's response to her harassment in the streets, Fazlalizadeh reestablishes the victim as the kind of entity that is entitled to express herself, to utter a response-the street art acknowledges the victim as a human (a human entitled to express herself), rather than a mere object. ${ }^{14}$

Fazlalizadeh's work provides an opportunity for those who have been silenced by negative identity prejudices to find their voice again. She provides a space for those who experience negative identity prejudices to correct for the epistemic injustices that they experience-street artists correct for these injustices on behalf of the victim, by making art that enables those victims to have a voice. ${ }^{15}$ This is one way that street art is able to correct for epistemic injustices that arise from negative identity prejudices.

Moreover, Fazlalizadeh's street art can serve to prevent future injustices as well in two different ways: first, the street art makes visible a particular negative identity prejudice against women, and second, the captions explain why the prejudice is wrong. When Fazlalizadeh's street artwork appears on the street, the poster corrects for three epistemic problems: (1) it makes known that a gender-based harassment occurred-that this location is the site of a gender-based epistemic injustice; (2) the quotation underneath the image explains the wrongness of the harassment; and (3) the presence of the poster also makes it publicly known that this harassment is wrong, and that action will be taken when such injustices occur.

The presence of these posters changes the range of future possible exchanges in social discourse on the streets by highlighting the wrongness of street harassment. The posters make it socially known to everyone in the neighbourhood that street harassment is socially unacceptable. By inserting the voice of those who are systematically neglected, ignored, or distorted, street artists influence and change the social dynamics that operate in the streets and images of women, and their responses serve as a surrogate female presence, rallying around the actual women walking in the streets-their voices have strength in numbers, regardless of whether their voice originates from an actual female or a surrogate street artwork.

The site specificity of street art also enables it to prevent future testimonial injustices, since placing the artwork at the site of the attack becomes evidence of an injustice, and the image and words testify to the public at large about the nature of the injustice; the woman makes it known, public knowledge that an injustice occurred, thereby delegitimating the attacker, and re-establishing her own social power in the social order. This is an intentional strategy on the part of Fazlalizadeh's project, which she describes here in an interview with Mother Jones when asked about the importance of making this project on the streets, instead of in a museum:

There's a huge difference. I am primarily an oil painter and a studio painter, so originally I was going to do an oil painting. It just kind of came to me to do it 
outside in the street. Men who are offenders of street harassment and women who experience street harassment can walk by and feel something about it, because it's out there in the environment where the harassment actually happens. So it's a lot more powerful than an oil painting that's stuck in a gallery or under my bed or in my studio where only a couple of eyes are going to see it, as opposed to it being in an environment where it could possibly effect a change. ${ }^{16}$

But, the street art also serves a preventative function too: those who might be genuinely unaware of the harmful effects of street harassment are also educated.

Although using these posters may well offer corrections for many injustices, it is sufficient for our purposes here to highlight that the street art serves as a tool for correcting testimonial injustice, because the correction involves allowing women to have a voice, to be heard.

In these cases, Fazlalizadeh's works are surrogate voices for the women-the women themselves are represented as having a voice. Her art gives them the voice that they did not have at the time of the harassment. In this way, the posters offer a kind of surrogate voice on behalf of these women. ${ }^{17}$

\section{Case 2: Black Lives Matter art movement}

Although many testimonial injustices occur as a single, identifiable event of silencing (like a moment of cat-calling), they are motivated by negative identity prejudices that result in systematic silencing or minimizing across a series of situations. In these cases, street art's presence can correct for a pattern of systemic or structural imbalances that result in denying a voice not just to a single individual at a single moment, but to a whole group of individuals, across a range of situations.

Much street art emerging out of the Black Lives Matter movement can be understood and interpreted as offering a corrective to negative identity prejudices against people of colour. In the U.S., the Black Lives Matter movement arose in response to the police violence against innocent Black men, as a way to raise awareness of the injustices (social, political, testimonial, and hermeneutic) against Blacks as a result of negative identity prejudices. This movement began as a social and political protest, but many artists took on the issues through their art. One example is Chris 30 Metzger's Inside Out Project in Baltimore:

Created in 2012 after the murder of Trayvon Martin, the movement [Inside Out Project in Baltimore] '[broadens] the conversation around state violence to include all of the ways in which Black people are intentionally left powerless at the hands of the state.' Part of French artist JR's global participatory art project Inside Out, our group action aims to shed light on the presence of invisible boundaries and limitations placed on Black people throughout different facets of their lives. ${ }^{18}$

This project presents murals of Blacks in Baltimore whose voices have been silenced simply in virtue of having their presence ignored. By placing these enormous images 
in the streets, these works literally make these people visible to the community around them.

This art highlights that many Blacks are not even acknowledged as members of the community. Painting them in life-size scale on walls forces the passersby to acknowledge or recognize their existence as members of the community-a necessary condition of being heard. Unlike Fazlalizadeh's works, whose works represent the specific persons who have experienced a testimonial injustice, Metzger's images are meant to represent any Black person in the community, and symbolize the silence that all Blacks experience in virtue of the negative identity prejudices against them. The individuals embody an entire social group.

The images are larger than life, dwarfing those who walk the streets. Where Blacks traditionally have been minimized, ignored and silenced, these works not only make their presence known, but the sheer, imposing size of these images corrects for the minimizing and silencing tactics experienced by Blacks. The larger-than-life representations serve as a tool for changing how we think about Black lives and for questioning why Black lives remain invisible. Although artists cannot change the prejudices that are ingrained in the social structures of a given community, their art visually and explicitly addresses the injustices experienced by these groups, and their art offers ways of making them visible to the general public. Their murals offer opportunities to open up discussions about these glaring discrepancies between how certain groups exist in reality and how they are represented in these artworks. That has several results: it communicates the experiences of Blacks, it offers some context and visual resources for understanding and appreciating those experiences, and it helps prevent silencing from happening in the future.

Unlike Fazlalizadeh's work, the goal of this project is not to provide a response on behalf of those who have experienced negative racial identity prejudices. Rather it is to communicate and to raise awareness of how negative identity prejudices silence Blacks.

\section{WHY STREET ART?}

Fazlalizadeh and Metzger are activists who create street art that is intentionally used as a tool to address the issue of epistemic injustice. Of course, activists can and do use many other methods of fighting for a cause-writing letters to the local newspapers, participating in public marches and demonstrations, filing grievances with the police, lobbying one's local political representative, and so on. These more traditional methods of activism are certainly less time-consuming (it's easier to write a letter or participate in a march than to paint a mural!) less financially burdensome (demonstrating is free, and letter writing costs at most a few dollars), and more strategically effective (organizing a march may be more effective in garnering media attention than drawing a picture on a wall), and much less risky (lobbying a congressperson is legal, while street art is not). So, why have activists recently adopted street art to correct epistemic injustice instead of these seemingly more straightforward alternatives?

The simple answer is that, for individuals who experience negative identity prejudices, these socially prescribed routes, like demonstrations or political lobbying, are usually ineffective: if those institutionally embedded, negative identity prejudices are 
already embedded within the system, then it is unlikely that approaching those organizations will successfully address the problems caused by those structural inequities. It's hard to change the structural institutional inequities by working within the system, or even by criticizing the system (as one might in a march or demonstration).

Moreover, even if you could change the structural institutional inequities by working within the system, there are independent reasons for activists to rely on street art as a tool for fighting epistemic injustice. Street art performs more functions and achieves more goals than could be achieved by working within the system.

First, street art represents a completely neutral playing field for raising awareness of issues of epistemic justice. There are no structural or institutional inequities on the walls of streets, and the streets can be used to construct an alternative system of communication with those who are marginalized and those who are engaging in marginalization.

Second, it's much more effective to correct for the testimonial injustices experienced by those who experience negative identity prejudice in the streets than in a museum or some other institutionally sanctioned environment. Art, unlike institutions, can communicate more immediately (as you go about your daily business), and over a longer period of time (unlike government documents which might be saved onto a desktop or printed and put in a folder, street art remains in your everyday environment over an extended period of time), and more easily to a wider group of people (stripped of government jargon and legalese) -it's a way of getting one's voice out to those who need to hear it to change those institutional structures. Street artists have control over the street, and as a result, they also have tacit control over the social imagination. They can, through their art, insert new ideas, voices, and experiences that might not otherwise be experienced by those in the community:

I personally don't think a mural by itself is an incredibly helpful thing. But I find as I'm talking to people that sometimes the things I paint take on a life after I've left that they didn't have when I was there. They mean things to people over time. Creating emblems and icons for people to gather around and talk about is definitely a useful thing to do, but I think there's more that has to get done. The visual element of any movement is always critical because it helps people remember it, helps people identify it, and helps people plug into it who weren't previously plugged in. But everything else has to happen in addition to that. There's definitely room for art in activism, but it's not end-all-be-all by any means. ${ }^{19}$

They can use their art to provide words, concepts, and ideas with which ordinary passersby might not otherwise be familiar. They can communicate and provide resources to make sense of certain social experiences to the marginalized. Street artists can make the marginalized visible in their art. And because their art is aconsensually produced, they don't need permission (tacit or explicit) to get their ideas out there-in contrast to museums, demonstrations, or letter-writing campaigns. 
Street art can challenge the status quo and correct for injustices in part because street artists can operate anonymously. Anonymity means that the artists are stripped of their identity, which renders it impossible for others to attach negative identity prejudices to the works. ${ }^{20}$ The anonymity of street art allows artists to opt out of identity politics that operate in the artworld. It also ensures the voice of the marginalized is not contaminated by negative identity prejudices. This forces the public to evaluate the art and its ideas for what they are, and the public must confront that art and the ideas for which the art stands, day in and day out, regardless of whether they accept it or not.

Street art requires no training or practice-those who make street art can effectively bypass institutional structures that would otherwise preclude their art being seen (artworld gatekeepers like attending a particular art school, or showing one's work at a particular gallery). This also opens the door to activists using street art to engage in activist projects undetected.

Street art is also site-specific and can be made quite quickly_it's an ideal tool for social and political issues. Such issues are often quite localized in particular neighbourhoods, and street art can offer an activist the possibility of a quick, targeted response or intervention at the site of the injustice.

When street artists make street art to correct for injustices, they are acting as a vehicle for communicating the voice of those who have been silenced. Street artists are acting as secondary agents by speaking on behalf of the silenced (either as a member of the silenced group, or on behalf of anyone in that marginalized group). And, the target of the communicative act is the passerby of specific, targeted areas. They can place their work in precisely those areas where epistemic injustices occur. People who wouldn't otherwise listen, people who are unable to see past their prejudices, are forced to literally confront the other person's point of view in street art. ${ }^{21}$ This is especially important in addressing hermeneutic injustices. Hermeneutic injustice arises when there is a gap in the social collective's resources; street art forces everyone to see the problem, and to think about solutions. It makes visible the problem (literally and metaphorically). Seeing these alternatives is a way of correcting for epistemic errors: it fosters a virtuous hearer's sensibility, promotes a critical openness, and shows how we can change our socialization patterns. Successful street art can also provide models of positive normalization - the use of art to visually represent certain identities as descriptively normal. This normalization of certain identities is key to addressing identity prejudices and their resulting harms.

\section{CONCLUSION}

I have argued here that street art can sometimes be effectively used as a tool by activists to correct for epistemic injustices for marginalized groups as a result of negative identity prejudices. These activists harness the distinctive features of the street (its anonymity, its ephemerality, its operation outside of institutional power structures, its ability to be located in key strategic areas, its public nature) in order to change the power dynamics in the public domain and to introduce new concepts, experiences, and resources to the social imagination. 
Of course, one might object that we would expect any good art (or even not so good art) to provide its audience with new conceptual resources, to help its audience see the world in a new way, and even to open the mind of the audience. In this respect, good street art is no different to what any good art ought to provide-whether it's in the streets or in a museum. But, where museum-based, institutionally sanctioned art departs from street art is what art can do with those conceptual resources-in the streets, they can be used as a tool for activism. Activist street art is interesting and successful, I think, in part because it is classified as (street) art, but being used as something else-viz., a tool for change.

And although street art has the potential to engage in social and political change more effectively than art in museums, this potential is certainly not always realized in all street art. Much street art is completely apolitical and is not used by activists; there's a lot of street art that has no role to play in advocating for change. All I have argued for here is that sometimes, street art can play a special and unique role in advocating for social change by providing opportunities to correct for testimonial and hermeneutic injustices; I have also argued that only art in the streets-aconsensually produced street art-has the power to play this role in correcting for epistemic injustice. And, this gives street art a special role to play in social and political justice.

\section{ACKNOWLEDGEMENTS}

I would like to thank Ramon Das, Deborah Tollefsen and John Haldane for helpful comments on earlier drafts, as well as the 2016 VUW Seminar series audience for feedback on an earlier version of this paper.

\section{NOTES}

1. See my "Street Art and Consent" (British Journal of Aesthetics 55/4 (2015), 481-95, in which I defend this view of street art. The thesis of this paper, that street art can sometimes be used as a tool for correcting for epistemic injustices, does not require adopting my account of street art in terms of aconsensuality (but my account nicely explains many features of how activists use street art as a tool).

2. For a delightful introduction to yarn-bombing (also known as graffiti or guerilla knitting), see Time Magazine's lovely photo-gallery, at http://content.time.com/time/photogallery/0,29307,2077071,00. html.

3. That's not to say that all street artists take advantage of such boundary crossings - much street art is entirely ordinary and does not protest anything.

4. For a general overview of the topic, see Rachel McKinnon, "Epistemic Injustice," Philosophy Compass 11/8 (2016), 437-46.

5. See Miranda Fricker, Epistemic Injustice: Power and the Ethics of Knowing, (Oxford: Oxford University Press, 2007), 45.

6. Fricker also considers many indirect epistemic harms as well, such as when those who are given less credibility doubt themselves.

7. Fricker, Epistemic Injustice, op. cit., 30.

8. Michelle Mason, “Two Kinds of Unknowing," Hypatia 26/2 (Spring 2011), 299.

9. We might consider whether this person lacks sufficient credibility, whether he is not heard, or whether even he is silenced. We will return to these fine-grained distinctions later.

10. Fricker, Epistemic Injustice, op. cit., 2.

11. Fricker offers this solution: "What is needed on the part of the hearer in order to avert a testimonial injustice-and in order to serve his own epistemic interest in the truth-is a corrective anti-prejudicial virtue that is distinctively reflexive in structure." (Fricker Epistemic Injustice, op. cit., 91, emphasis not mine). 
Karen Frost-Arnold suggests: "In sum, online acts of hopeful trust that reach a large audience may provide enough motivation to some susceptible audience members that it inspires them to change. It is the possibility for this kind of change that makes it sometimes effective to use social media to challenge privilege and prejudice." See her "Social Media, Trust, and the Epistemology of Prejudice," Social Epistemology 30/5-6 (2016), 513-31, 527.

12. This case might count as testimonial quieting, when someone is not recognized as a potential testifier or knower, in virtue of belonging to a social group whose stereotypes strip them of any ability to speak. See Kristie Dotson, “Tracking Epistemic Violence, Tracking Practices of Silencing," Hypatia 26/2 (Spring 2011), 243.

13. http://stoptellingwomentosmile.com.

14. I take the case of cat-calling to involve a situation where the woman is deprived of her ability to engage in illocutionary reciprocity_cat-calling is a speech act in which the woman is shut down and in which the woman is denied the opportunity to respond. This seems to fulfill Hornsby's category of silencing through inaudibility, where a woman is not heard because of a breakdown in reciprocity required for a meaningful illocutionary exchange. See Jennifer Hornsby, “Disempowered Speech,” Philosophical Topics 23/2, Feminist Perspectives on Language, Knowledge, and Reality (Fall 1995), 136-38.

15. Street artists are acting as secondary agents - making art to respond on behalf of the victims.

15. http://www.motherjones.com/media/2013/11/tatyana-fazlalizadeh-artist-street-harassment-stop-tellingwomen-smile.

17. One might object that correcting for the testimonial injustice requires the woman herself to get her voice back; but here the woman is represented by the artist as having a voice. I see this as a case of secondary agency, i.e., the artist is giving the woman a voice, on behalf of the woman. Another concern might be that the artist is making the utterance, not the woman who experiences the harassment. Against this concern two responses can be made: first, the artist represents the woman. So, Fazlalizadeh responds on her behalf by placing her portrait and response at the site of the injustice. Fazlalizadeh is acting as a secondary agent, providing the response on behalf of the harassed.

18. https://vimeo.com/148445452 from a statement about \#BlackLivesMatter Inside Out Project Baltimore.

19. https://www.vice.com/en_au/article/a-black-lives-matter-painter-explains-how-art-can-be-activism, images by Langston Allston in Baton Rouge.

20. This case may be a second kind of exception to Sanford Goldberg's claim that anonymity in assertions "has a diminishing effect on the sort of (assertion-generated) expectations that speakers and hearers are entitled to have of one another." See his Chapter 11, "Anonymous Assertions" in Assertions: On the Philosophical Significance of Assertoric Speech, (Oxford: Oxford University Press, 2015).

21. Street art functions like social media in creating what Karen Frost-Arnold calls "hopeful trust," allowing members of oppressed groups to combat socially constructed ignorance. See her "Social Media, Trust, and the Epistemology of Prejudice," op. cit. 